\title{
The Rheology and Performance of Geothermal Spring Water-Based Drilling Fluids
}

\author{
Emine Avci $(1)$ and Bayram Ali Mert $(1 D$ \\ Iskenderun Technical University, Faculty of Engineering and Natural Sciences, Department of Petroleum and Natural \\ Gas Engineering, 31200 Iskenderun, Hatay, Turkey \\ Correspondence should be addressed to Bayram Ali Mert; bali.mert@iste.edu.tr
}

Received 30 November 2018; Revised 12 March 2019; Accepted 7 April 2019; Published 2 May 2019

Guest Editor: Bisheng Wu

Copyright (C) 2019 Emine Avci and Bayram Ali Mert. This is an open access article distributed under the Creative Commons Attribution License, which permits unrestricted use, distribution, and reproduction in any medium, provided the original work is properly cited.

\begin{abstract}
In this study, the rheological properties and performances of mud prepared with geothermal spring water to be used by geothermal drilling operators were examined at ambient and elevated temperatures. In this context, mud samples were prepared in the compositions detailed in the API specification by using five different geothermal spring water types and a distilled water type. Afterwards, density, apparent viscosity, plastic viscosity, yield point, gel strength, fluid loss, $\mathrm{pH}$, and filter cake thickness of these samples were measured. The drilling muds were analyzed by means of rheological tests in accordance with the standards of the American Petroleum Institute (API). The experimental results have revealed that the mud prepared with geothermal water have lower viscosity and yield point compared to those prepared with freshwater at elevated temperatures. The stability of the muds decreases, especially at temperatures higher than $250^{\circ} \mathrm{F}$, and they start to become flocculated. It was concluded that geothermal water-based muds have higher API fluid loss and cake thickness than the freshwater-based one. Therefore, it could be interpreted that the muds prepared with geothermal spring water will exhibit lower flow performance and lower ability of hole cleaning and rate of penetration compared to the freshwater muds. Hence, it is recommended that this kind of water should not be used to prepare drilling mud.
\end{abstract}

\section{Introduction}

Drilling fluids are an important circulation component for the drilling process [1]. The drilling fluids are basically divided into three categories according to their continuous phase: water-based muds, oil-based muds, and gas-based muds [2]. A typical water-based mud usually consists of suspension of clay particles in water. Some of the main functions of the muds are transporting of cuttings, lubricating of drill string, preventing an influx of formation fluids, controlling the hydrostatic pressure, and stabilizing the well $[3,4]$. The drilling muds must have certain rheological and filtration properties in order to perform these functions [5]. It is relatively difficult to maintain these properties of the mud during geothermal drilling $[6,7]$. As it is well-known, geothermal drillings are carried out under hot and naturally fractured and/or vugular formations where they cause a large amount of lost circulation and degradation [8]. The lost circulation is one of the most complicated problems that have existed in drilling engineering and leads to the requirement for a large volume of drilling fluid [9]. Therefore, it is significant for the operators to provide water from the source closest to the well site, both economically and technically. Operators sometimes use a geothermal spring source which is close to the well site to prepare drilling mud. In geothermal systems, geothermal water ascends to the surface by reacting with the subsurface formations causing mineral dissolution, so the variety and concentration of dissolved constituents in the geothermal waters are higher than those of freshwaters. The geothermal water composition is characterized by the macroelements of the reservoir rock and the subsurface environment to which it is exposed most of the time. The most frequently observed ions with high concentrations are $\mathrm{Na}^{+}, \mathrm{K}^{+}, \mathrm{Ca}^{2+}, \mathrm{Mg}^{2+}, \mathrm{HCO}_{3}{ }^{-}, \mathrm{CO}_{3}{ }^{2-}, \mathrm{SO}_{4}{ }^{2-}$, and $\mathrm{CO}_{2}$. Other micropollutants are heavy metals such as mercury, copper, lead, silver, iron, zinc, arsenic, manganese, chromium, 
beryllium, selenium, vanadium, cadmium, nickel, strontium, uranium, cobalt, gallium, and antimony. Some other elements of boron and silica could be present in geothermal waters as well [10]. Therefore, these waters are likely to affect the drilling fluid properties such as rheology, fluid loss, shale inhibition, and lubricity.

There are various studies in the literature regarding the change in rheological and filtration properties depending on temperature, pressure, various contaminants and some additives, or the chemistry of the clays used. Some of these studies examined the effect of various additives on rheological properties without changing the fluids used to prepare mud while others have studied the effect of different fluids on rheological properties by keeping the additives constant. For instance, Vipulanandan and Mohammed [11] used nanoclays, Jain et al. [12] used nanocomposites, Kang et al. [13] used nanoparticles, Cai et al. [14] used nanosilicates, Li et al. [15] used cellulose nanocrystals, Navarrete et al. [16] used guar gum, Yan et al. [17] used synthetic polymers, Mahto and Sharma [18] used tamarind gum, Ahmad et al. [19] used acrylamide-based copolymer, and Meng et al. [20] used carbon ash as an additive to examine the effects on drilling mud. As a result, they observed that these additives improved the rheological properties to be present in an effective drilling mud. Luo et al. [4] and Ofei et al. [21] have used ionic liquids as an additive for drilling muds, and they concluded that these liquids reduce fluid loss by improving the rheological properties of drilling muds even at elevated temperatures. Kelessidis et al. [22] and Abu-Jdayil [23] analyzed the rheological properties of drilling muds prepared with salty water. They have stated that viscosity and yield point decreased whereas the filtrate volume increased as the concentration of salt increased. Furthermore, they observed that mud samples present shear thickening behavior with an increase in salt content. Zhao et al. [24] studied the effect of $\mathrm{Na}, \mathrm{K}, \mathrm{Mg}$, and $\mathrm{Ca}$ inorganic salt cations on the rheological properties of the polyacrylamide/xanthan gum solution for drilling mud and concluded that these cations affected rheological properties negatively and reduced the viscosity and cutting capacity significantly at high concentrations. Willson et al. [25], Choi et al. [26], and Mao et al. [27] examined the performance of drilling mud prepared by seawater.

In this study, the rheological and filtration characteristics of drilling muds prepared with geothermal spring water were examined, and their effects on drilling performance were revealed.

\section{Materials and Methods}

2.1. Materials. Four different geothermal spring water samples obtained from various geothermal areas $(g s 1, g s 2, g s 3$, and $g s 4)$, distilled water ( $d w 1)$, Na-bentonite being the most commonly used clay type in drilling mud, XCD (xantham gum) for modifying viscosity, and CMC (carboxymethyl cellulose) for controlling fluid loss were used to prepare the mud samples. The chemical properties of geothermal spring water and distilled water are given in Table 1.
TABLE 1: Chemical properties of geothermal spring water samples and distilled water sample.

\begin{tabular}{lccccc}
\hline \multirow{2}{*}{ Chemical parameters } & \multicolumn{5}{c}{ Samples } \\
& $g s 1$ & $g s 2$ & $g s 3$ & $g s 4$ & $\mathrm{dwl}$ \\
\hline $\mathrm{pH}$ & 7.41 & 7.72 & 8.33 & 7.64 & 8.10 \\
Specific conductivity $(\mu \mathrm{S} / \mathrm{cm})$ & 6714 & 3015.5 & 2028 & 1805 & 10.49 \\
$\mathrm{~K}^{+}(\mathrm{mg} / \mathrm{L})$ & 98.8 & 26 & 33.2 & 34 & - \\
$\mathrm{Na}^{+}(\mathrm{mg} / \mathrm{L})$ & 1215 & 256 & 423 & 363 & 1.42 \\
$\mathrm{NH}_{4}(\mathrm{mg} / \mathrm{L})$ & $<0.1$ & 1.28 & 1.92 & 1.82 & - \\
$\mathrm{Ca}^{2+}(\mathrm{mg} / \mathrm{L})$ & 97 & 287 & 22.4 & 28.8 & 0 \\
$\mathrm{Mg}^{2+}(\mathrm{mg} / \mathrm{L})$ & 17.5 & 34.3 & 0.72 & 8.64 & 0 \\
$\mathrm{As}_{(\mathrm{T})}(\mathrm{mg} / \mathrm{L})$ & - & $<0.05$ & - & - & 0 \\
$\mathrm{~B}_{(\mathrm{T})}(\mathrm{mg} / \mathrm{L})$ & 5.6 & 0.2 & 15.1 & 12.3 & 0 \\
$\mathrm{Li}^{+}(\mathrm{mg} / \mathrm{L})$ & 1.5 & - & 1.05 & 0.98 & - \\
$\mathrm{SiO}_{2}(\mathrm{mg} / \mathrm{L})$ & 81 & 56 & 203 & 187 & - \\
$\mathrm{CO}_{2}(\mathrm{mg} / \mathrm{L})$ & 0.5 & 7.47 & - & - & - \\
$\mathrm{HCO}_{3}^{-}(\mathrm{mg} / \mathrm{L})$ & 7.6 & 245 & 580 & 626 & - \\
$\mathrm{CO}_{3}^{2-}(\mathrm{mg} / \mathrm{L})$ & $<10$ & $<10$ & 90 & 0.0 & - \\
$\mathrm{SO}_{4}{ }^{2-}(\mathrm{mg} / \mathrm{L})$ & 432 & 839 & 139 & 141 & 1 \\
$\mathrm{Cl}^{-}(\mathrm{mg} / \mathrm{L})$ & 1670 & 325 & 216 & 196 & 0.34 \\
$\mathrm{~F}^{-}(\mathrm{mg} / \mathrm{L})$ & - & $<0.1$ & - & - & - \\
$\mathrm{NO}_{2}^{-}(\mathrm{mg} / \mathrm{L})$ & - & $<0.1$ & $<0.05$ & $<0.05$ & 0 \\
$\mathrm{NO}_{3}^{-}(\mathrm{mg} / \mathrm{L})$ & - & 12.4 & 4.1 & 3.7 & - \\
$\mathrm{Salinity}^{-}(\mathrm{ppt})$ & - & - & 1.0 & 0.9 & - \\
$\mathrm{TDS}^{(\mathrm{mg} / \mathrm{L})}$ & - & - & 1504 & 1390 & - \\
$\mathrm{Fe}_{(\mathrm{T})}(\mathrm{mg} / \mathrm{L})$ & - & - & 0.46 & 0.475 & 0 \\
\hline
\end{tabular}

The crystallographic properties of the sample used in this study were determined using a Rigaku Miniflex II X-ray diffractometer equipped with $\mathrm{Cu} \alpha$ radiation in the $2 \theta$ range of $3-90^{\circ}$ with a 0.01 step size and $0.5 \mathrm{deg} / \mathrm{min}$, and the patterns were evaluated using a PDXL software program for mineral identification. The pattern given in Figure 1 shows that the bentonite sample was composed of sodium-rich montmorillonite (NaM) mineral together with quartz, clipoptilolite, albite, and illite which were identified as impurities.

The elemental analysis of bentonite sample was performed by X-ray fluorescence (XRF) using a Thermo ARL $\mathrm{X}$-ray spectrometer. From the obtained results, it is found that the Na-bentonite sample is composed mainly of $\mathrm{SiO}_{2}$ (61.59wt\%), $\mathrm{Al}_{2} \mathrm{O}_{3}$ (15.88wt\%), and $\mathrm{Fe}_{2} \mathrm{O}_{3}$ (5.62 wt\%), in addition to $\mathrm{Na}_{2} \mathrm{O}$ (2.71 wt\%), $\mathrm{MgO}$ (2.21 wt\%), $\mathrm{CaO}$ (1.53 wt \%), $\mathrm{K}_{2} \mathrm{O}(1.07 \mathrm{wt} \%), \mathrm{TiO}_{2}(0.92 \mathrm{wt} \%)$, and L.O.I. (7.82 wt\%) trace elements in the bentonite which are $\mathrm{P}_{2} \mathrm{O}_{5}$, $\mathrm{MnO}, \mathrm{SrO}, \mathrm{NiO}, \mathrm{CuO}, \mathrm{ZnO}$, and $\mathrm{ZrO}_{2}$. These results showed that the $\mathrm{Al}_{2} \mathrm{O}_{3} / \mathrm{SiO}_{2}$ ratio was about $1 / 3$ to $1 / 4$ as expected for montmorillonite which is the main component of bentonite used in the study.

2.2. Preparation of Drilling Mud Samples. The mud samples were prepared in the compositions detailed in the American Petroleum Institute (API) specification [28]. As shown in Figure $2,500 \mathrm{~mL}$ of geothermal spring water was stirred with $32.14 \mathrm{~g}$ of bentonite for 20 minutes to maintain the clay- 


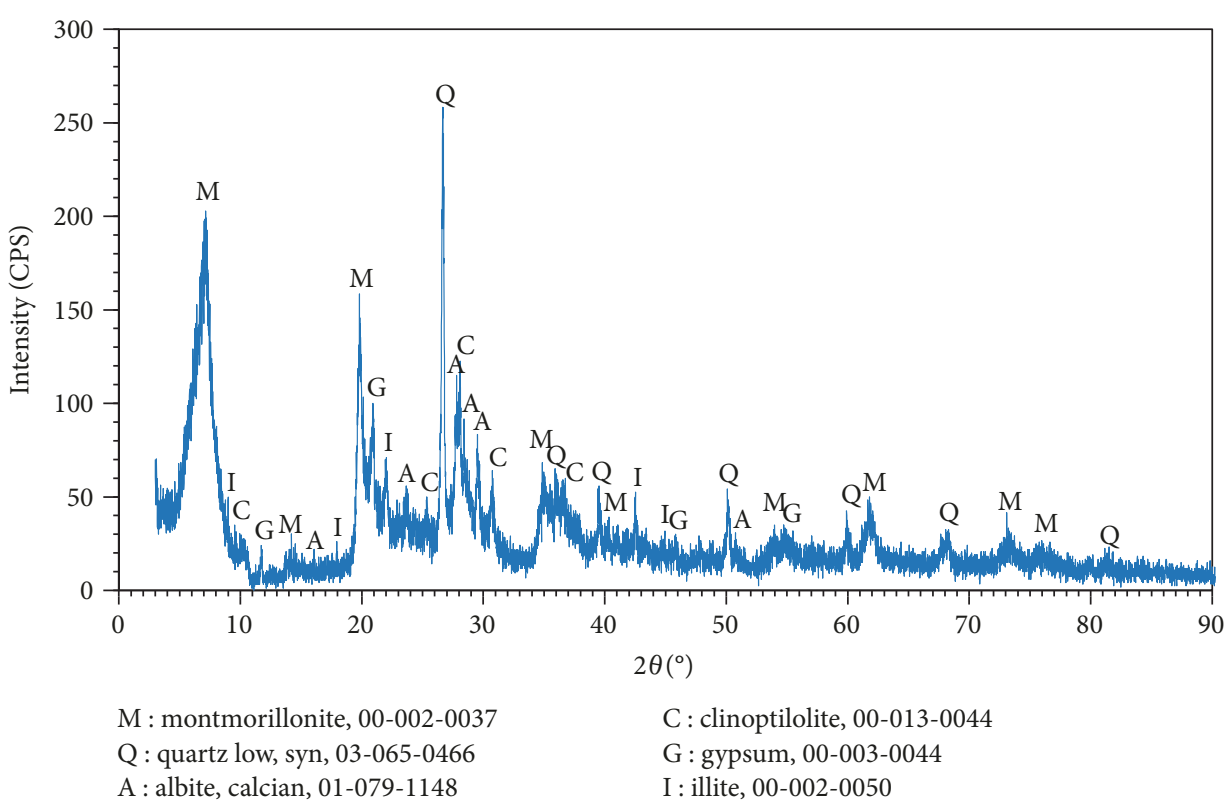

FIGURE 1: X-ray diffraction (XRD) of Na-bentonite.

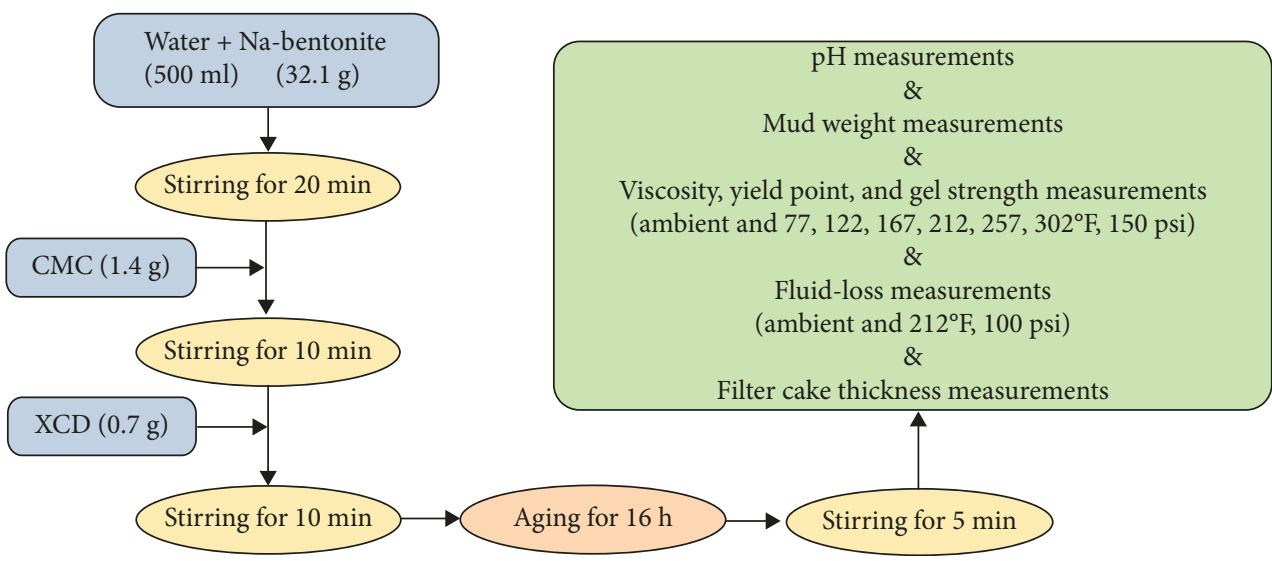

Figure 2: Flowchart of the experimental procedure.

water ratio according to API standards. Then, $1.4 \mathrm{~g}$ of CMC and $0.7 \mathrm{~g}$ of XCD were added to the solution, respectively. Finally, the solution was stirred for 10 minutes to form a homogeneous mixture. A Hamilton-Beach multiple mixer (model 9B) was used for mixing.

The above process was repeated for each geothermal spring water, and a total of four different mud samples were prepared. These samples were labeled as $S 1, S 2, S 3$, and $S 4$. Moreover, a sample was prepared with $500 \mathrm{~mL}$ of distilled water as base fluid in order to examine the effects of the water on the mud by following the steps. This sample was also labeled as D1. Prepared samples were remained in static condition at room temperature for 16 hours as specified in the API standard for bentonite clay. The five mud samples labeled $S 1, S 2, S 3, S 4$, and $D 1$ were subjected to rheological and filtration tests. These tests were mud weight, viscosity, gel strength, fluid loss, and mud cake thickness measurements, respectively.
2.3. Determination of Rheological Properties. In the experimental study, API Standard Procedures were used in order to determine rheological properties [29].

The weight of the considered mud samples was determined by using the conventional OFITE (model 900) mud balance at ambient temperature, while the rheological properties (viscosity, yield point, and gel strength) were measured at both ambient and elevated temperatures by means of a Fann model 35 viscometer and Fann model 50 SL rheometer, respectively. Since the temperatures of geothermal resources ranged between $30^{\circ} \mathrm{C}\left(86^{\circ} \mathrm{F}\right) \pm 150^{\circ} \mathrm{C}\left(302^{\circ} \mathrm{F}\right)$ [30], viscometer shear stress dial readings were obtained under 77, 122, 167, 212, 257, and $302\left({ }^{\circ} \mathrm{F}\right)$ temperatures and 150 psi pressure every five seconds for each standard shear rate $(3,6,100$, 200,300 , and $600 \mathrm{rpm}$ ).

The Bingham plastic, power-low, and Herschel-Bulkley models are the fundamental models to describe the behavior of drilling mud [2]. Moreover, Vipulanandan [31] and 
hyperbolic models $[32,33]$ have been used for the same purpose recently. However, drilling fluid is generally considered to be classified as Bingham plastic in the drilling industry and the rheological properties of drilling mud are determined based on this model [20,34].

According to the Bingham plastic model, the apparent viscosity, plastic viscosity, and yield point were calculated using the following equations from 600 and $300 \mathrm{rpm}$ reading:

$$
\begin{aligned}
\text { Apparent viscosity }(\mathrm{AV}) & =\frac{\theta_{600}}{2(\mathrm{mPas})}, \\
\text { Plastic viscosity }\left(\mu_{\mathrm{p}}\right) & =\theta_{600}-\theta_{300}(\mathrm{mPas}), \\
\text { Yield point }\left(y_{\mathrm{p}}\right) & =0.5\left(\theta_{300}-\mu_{\mathrm{p}}\right)(\mathrm{Pa}) .
\end{aligned}
$$

The gel strength of muds was measured with the rotating viscometer. After that, the mud samples were immobilized for 10 seconds and 10 minutes. The maximum deflection value seen at $3 \mathrm{rpm}$ was found as 10 -second gel and 10minute gel, respectively.

Fluid-loss measurements were conducted both at ambient and $212^{\circ} \mathrm{F}$ temperature conditions. The measurements at ambient temperature were performed using a LPLT (low pressure-low temperature) filter press, and the measurements at $212^{\circ} \mathrm{F}$ were made using the Fann $500 \mathrm{~mL}$ filter press in a pressure of 100 psi.

After the fluid-loss measurements, the mud cake on the No. 50 filtrate paper was left to evaporate water at ambient temperature for 24 hours, then the thickness of the mud cake was measured with a Vernier-type caliper.

\section{Results and Discussion}

The shear stress values and their relationship with the mud samples prepared with $S 1-4$ and $D 1$ are given in Figure 3 under both ambient and elevated temperatures (77, 122, $167,212,257$, and $\left.302\left({ }^{\circ} \mathrm{F}\right)\right)$.

Figures 3(a)-3(f) reveal that the relationship between the shear stress and the shear rate is not linear between 0 and $100 \mathrm{rpm}$, but linearly increases up to $600 \mathrm{rpm}$, so the behavior of these samples can be described by the two-parameter Bingham plastic model, which assumes a linear relationship between the shear stress and the shear rate. As a matter of fact, the Bingham plastic model does not accurately predict fluid flow behavior at low shear rates but is useful for continuous monitoring and treating of drilling fluids. Fluids that exhibit Bingham plastic behavior do not flow until the shear stress exceeds a critical value known as the yield point. Once the yield point is reached, changes in shear stress and shear rate are proportional. This constant of proportionality, or the slope of the curve, is termed plastic viscosity. Moreover, it has been highlighted that shear stress values decreased as temperature increased for all the samples due to the thermal degradation of the components of the mud samples. When the rheograms are compared, it is seen that the shear stress values of the $D 1$ sample is higher than those of $S 1, S 2, S 3$, and $S 4$ samples in all terms and conditions. For all samples, the shear stress values decreased at 257 and $302\left({ }^{\circ} \mathrm{F}\right)$ temperatures and low shear rate (3-6 (rpm)). Normally, it is expected that the shear stress increases with the increase in the shear rate value. Nevertheless, bentonite muds can maintain their stability up to $250^{\circ} \mathrm{F}$ and show shear thickening behavior at temperatures higher than $250^{\circ} \mathrm{F}$. Therefore, gelling and filtration problems will occur at temperatures higher than $250^{\circ} \mathrm{F}$ in the boreholes where these drilling muds are used. These problems will cause the drilling fluid to flow into formation and reduce the carrying capacity.

Table 2 shows AV, PV, and YP and the ratio of YP to PV of the drilling mud samples depending on the temperature.

As can be seen in Table 2, temperature affects the AV of geothermal and freshwater muds negatively. On the other hand, the AV of freshwater mud is greater than that of geothermal water muds at constant temperature. As AV shows the flowability of the drilling mud and affects the rate of penetration, it could be noted that the muds prepared with geothermal spring water will have lower flow performance.

From Table 2, it is seen that the PV of the muds prepared with geothermal spring water is lower than that of mud prepared with freshwater at all temperatures. This indicates that the spring water causes reduction in bentonite swelling ability compared to distilled water. This difference is the result of the different concentration of dissolved solid in the content of geothermal water and distilled water and leads to a difference in the viscosity of water that is used to prepare mud samples, in which the viscosity of water is one of the factors affecting plastic viscosity. The yield point of the all samples varies considerably with elevated temperature. Furthermore, similar to the viscosity, the highest yield point values are seen for the D1 sample at all temperatures. The low YP will cause drilling mud not to meet the task of suspending the cuttings and carrying capacity. In addition, the plastic viscosities of the samples generally decrease up to $167^{\circ} \mathrm{F}$ temperature. Although an increase is observed in a temperature range from $167^{\circ} \mathrm{F}$ to $212^{\circ} \mathrm{F}$, it decreases consistently at the temperatures higher than $212^{\circ} \mathrm{F}$. However, the plastic viscosity of the $S 2$ sample decreases continuously at temperatures higher than $167^{\circ} \mathrm{F}$. Although fluctuations are observed for the yield points of the samples up to $167^{\circ} \mathrm{F}$, the yield points of all samples reduce distinctly at temperatures higher than $167^{\circ} \mathrm{F}$. Interestingly, the yield point of the $S 2$ sample reached a negative value at 257 and $302\left({ }^{\circ} \mathrm{F}\right)$. This could be due to the wall slip phenomena. Wall slip is a common problem during rheology measurements of drilling fluids and is defined as a difference between the velocity of the walls of the measuring geometry and of the adjacent fluid layer [35]. The low shear rate [36] is one of the parameters in which "wall slip" is traditionally associated.

Shear thinning behavior is a desired property as it provides a reduction in the pumping pressure and an improvement in the rate of penetration when the viscosity is low in the pipes and where the drilling mud has a high shear rate. The YP/PV ratio is the measurement of the shear thinning as well $[1,37]$. When the ratio gets higher, the shear thinning becomes greater $[1,2]$. It is observed that the YP/PV ratio is the highest for the D1 sample in all conditions. Moreover, this ratio should be at least $0.375 \mathrm{~Pa} / \mathrm{mPas}$ to 

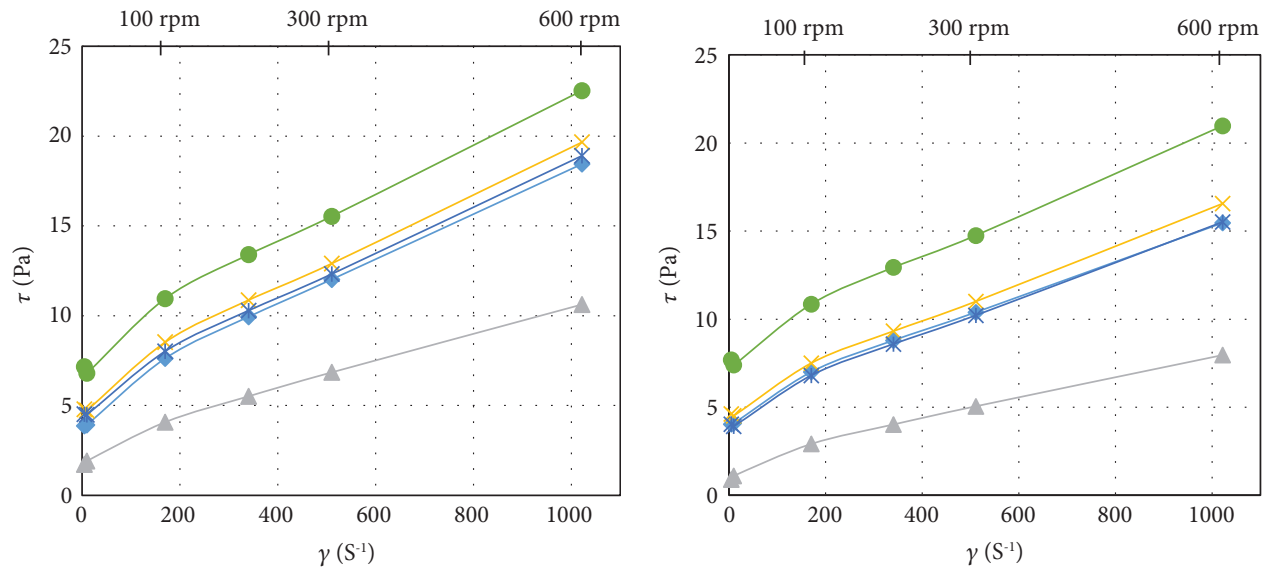

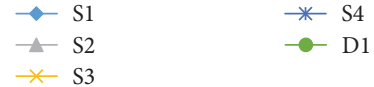

(a)
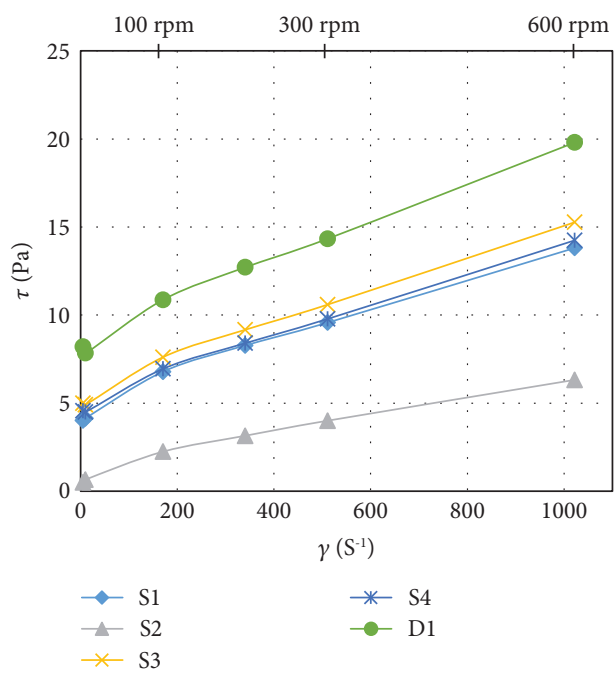

(c)

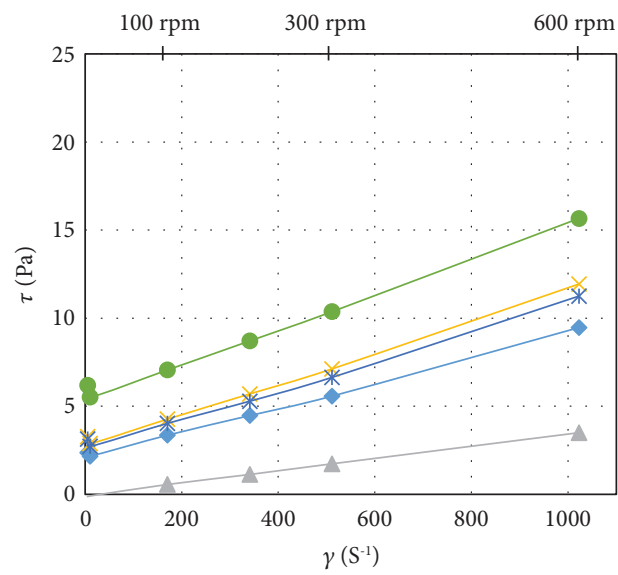

$$
\begin{aligned}
& \rightarrow \mathrm{S} 1 \\
& \rightarrow \mathrm{S} 2 \\
& \rightarrow \mathrm{S3}
\end{aligned}
$$

$\underset{\rightarrow-\mathrm{D} 1}{\rightarrow-\mathrm{D} 1}$

(e)

$$
\begin{array}{ll}
\rightarrow-\mathrm{S} 1 & * \mathrm{~S} 4 \\
\rightarrow \mathrm{S} 2 & \rightarrow \mathrm{D} 1 \\
\leftarrow \text { S3 } &
\end{array}
$$

(b)

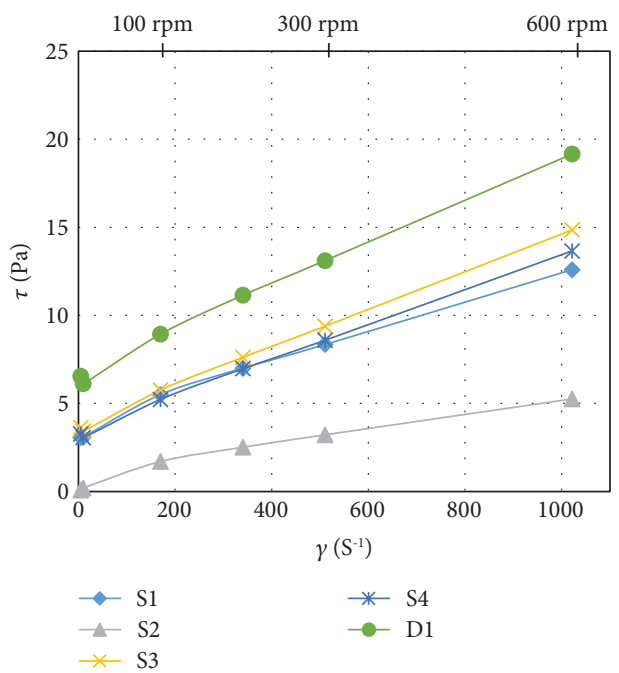

(d)
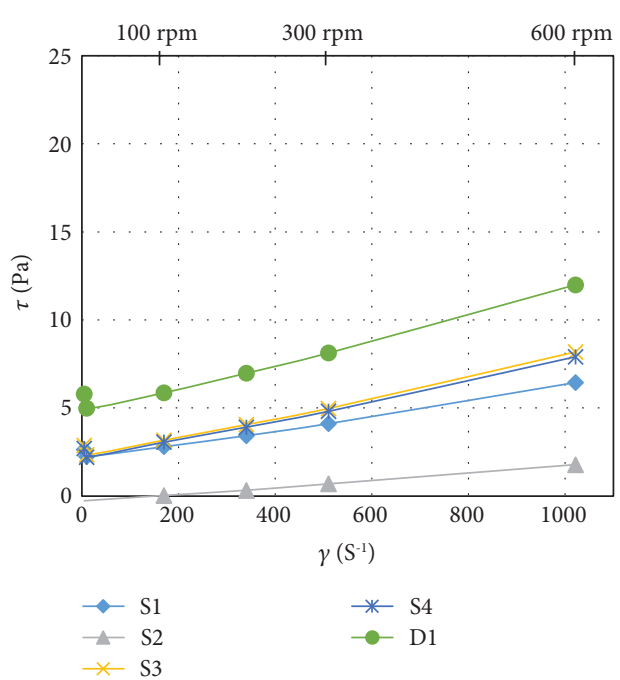

(f)

Figure 3: The rheograms of the $S 1, S 2, S 3, S 4$, and $D 1$ samples at constant temperatures (a) $77^{\circ} \mathrm{F}$, (b) $122^{\circ} \mathrm{F}$, (c) $167^{\circ} \mathrm{F},(\mathrm{d}) 212^{\circ} \mathrm{F},(\mathrm{e}) 257^{\circ} \mathrm{F}$, and (f) $302^{\circ} \mathrm{F}$. 
TABLE 2: Rheological properties of drilling mud samples.

\begin{tabular}{|c|c|c|c|c|c|}
\hline Samples & $S 1$ & $S 2$ & S3 & $S 4$ & D1 \\
\hline \multicolumn{6}{|c|}{$\begin{array}{l}\text { Apparent viscosity } \\
(\mathrm{AV}) \mathrm{mPas} \text { at } 150 \mathrm{psi}\end{array}$} \\
\hline Amb. con & 17.305 & 11.180 & 19.700 & 18.900 & 22.895 \\
\hline $77^{\circ} \mathrm{F}$ & 19.265 & 11.095 & 20.535 & 19.747 & 23.535 \\
\hline $122^{\circ} \mathrm{F}$ & 16.154 & 8.315 & 17.298 & 16.209 & 21.910 \\
\hline $167^{\circ} \mathrm{F}$ & 14.422 & 6.604 & 15.948 & 14.874 & 20.675 \\
\hline $212^{\circ} \mathrm{F}$ & 13.153 & 5.490 & 15.506 & 14.267 & 20.008 \\
\hline $257^{\circ} \mathrm{F}$ & 9.881 & 3.648 & 12.465 & 11.748 & 16.354 \\
\hline $302^{\circ} \mathrm{F}$ & 6.735 & 1.867 & 8.551 & 8.260 & 12.526 \\
\hline \multicolumn{6}{|c|}{$\begin{array}{l}\text { Plastic viscosity (PV) } \\
\mathrm{mPas} \text { at } 150 \mathrm{psi}\end{array}$} \\
\hline Amb. con. & 9.590 & 6.920 & 10.650 & 10.650 & 10.650 \\
\hline $77^{\circ} \mathrm{F}$ & 13.404 & 7.887 & 14.097 & 13.748 & 14.602 \\
\hline $122^{\circ} \mathrm{F}$ & 10.602 & 4.489 & 11.609 & 11.073 & 13.004 \\
\hline $167^{\circ} \mathrm{F}$ & 8.847 & 4.838 & 9.763 & 9.312 & 11.411 \\
\hline $212^{\circ} \mathrm{F}$ & 8.870 & 4.253 & 11.401 & 10.588 & 12.625 \\
\hline $257^{\circ} \mathrm{F}$ & 8.129 & 3.690 & 10.068 & 9.640 & 11.060 \\
\hline $302^{\circ} \mathrm{F}$ & 4.877 & 2.282 & 6.707 & 6.464 & 8.079 \\
\hline \multicolumn{6}{|c|}{$\begin{array}{l}\text { Yield point (YP) } \mathrm{Pa} \\
\text { at } 150 \mathrm{psi}\end{array}$} \\
\hline Amb. con. & 7.884 & 4.353 & 9.249 & 8.431 & 12.514 \\
\hline $77^{\circ} \mathrm{F}$ & 5.985 & 3.279 & 6.578 & 6.130 & 9.129 \\
\hline $122^{\circ} \mathrm{F}$ & 5.673 & 4.248 & 5.813 & 5.247 & 9.100 \\
\hline $167^{\circ} \mathrm{F}$ & 5.697 & 1.804 & 6.320 & 5.683 & 9.467 \\
\hline $212^{\circ} \mathrm{F}$ & 4.376 & 1.264 & 4.194 & 3.758 & 7.543 \\
\hline $257^{\circ} \mathrm{F}$ & 1.789 & -0.04 & 2.449 & 2.153 & 5.410 \\
\hline $302^{\circ} \mathrm{F}$ & 1.897 & -0.41 & 1.884 & 1.835 & 4.543 \\
\hline \multicolumn{6}{|c|}{$\begin{array}{l}\mathrm{YP} / \mathrm{PV} \mathrm{Pa} / \mathrm{mPas} \\
\text { at } 150 \mathrm{psi}\end{array}$} \\
\hline Amb.con. & 0.822 & 0.629 & 0.868 & 0.791 & 1.175 \\
\hline $77^{\circ} \mathrm{F}$ & 0.446 & 0.415 & 0.466 & 0.445 & 0.625 \\
\hline $122^{\circ} \mathrm{F}$ & 0.535 & 0.946 & 0.500 & 0.473 & 0.699 \\
\hline $167^{\circ} \mathrm{F}$ & 0.643 & 0.372 & 0.647 & 0.610 & 0.829 \\
\hline $212^{\circ} \mathrm{F}$ & 0.493 & 0.297 & 0.367 & 0.354 & 0.597 \\
\hline $257^{\circ} \mathrm{F}$ & 0.220 & -0.01 & 0.243 & 0.223 & 0.489 \\
\hline $302^{\circ} \mathrm{F}$ & 0.388 & -0.41 & 0.280 & 0.283 & 0.562 \\
\hline
\end{tabular}

achieve sufficient hole cleaning $[4,21]$. The $\mathrm{YP} / \mathrm{PV}$ ratio of the D1 sample is higher than $0.375 \mathrm{~Pa} / \mathrm{mPas}$ at all temperatures. However, it is noted that the ratio of geothermal water-based mud samples is below this value at temperatures above $212^{\circ} \mathrm{F}$. This indicates that freshwater bentonite muds exhibit more shear thinning behavior compared to geothermal water-based bentonite muds. As the ratio decreases depending on temperature, muds prepared using geothermal water will adversely affect the hole cleaning and penetration rate. Therefore, it will directly cause a considerable increase in the cost of drilling.

Density, gel strength, mud cake thickness, $\mathrm{pH}$, and fluid loss tests were also performed. The results are shown in Table 3.
TABLE 3: The other rheological properties of the drilling mud samples.

\begin{tabular}{lccccc}
\hline & $S 1$ & $S 2$ & $S 3$ & $S 4$ & $D 1$ \\
\hline Density $\left(\mathrm{g} / \mathrm{cm}^{3}\right)$ & 1.031 & 1.031 & 1.031 & 1.031 & 1.031 \\
Filtration $\mathrm{pH}$ at $75^{\circ} \mathrm{F}$ & 6.0 & 7.0 & 8.0 & 8.0 & 7.0 \\
Filter cake thickness $(\mathrm{mm})$ & 0.13 & 0.15 & 0.12 & 0.15 & 0.11 \\
Gel strength $\left(\mathrm{lb} / 100 \mathrm{ft}^{2}\right)$ & $7.5 / 17$ & $4 / 8$ & $10 / 27$ & $12 / 27$ & $16 / 19$ \\
$10 \mathrm{~s} / 10$ min & & & & & \\
API fluid loss cc at $100 \mathrm{psi}$ & & & & & \\
and amb. temperature & & & & & \\
$30 \mathrm{~s}$ & 0.5 & 0.8 & 0.5 & 0.3 & 0.8 \\
$1 \mathrm{~min}$ & 0.8 & 1.2 & 1.0 & 0.5 & 1.2 \\
$3 \mathrm{~min}$ & 2.1 & 2.5 & 1.6 & 1.5 & 1.7 \\
$5 \mathrm{~min}$ & 2.6 & 3.5 & 2.4 & 2.3 & 2.4 \\
$7.5 \mathrm{~min}$ & 3.4 & 4.4 & 3.3 & 3.0 & 3.2 \\
$10 \mathrm{~min}$ & 4.2 & 5.3 & 3.9 & 3.7 & 3.7 \\
$15 \mathrm{~min}$ & 5.4 & 6.6 & 5.1 & 4.8 & 4.8 \\
$20 \mathrm{~min}$ & 6.4 & 7.7 & 6.0 & 5.7 & 5.1 \\
$25 \mathrm{~min}$ & 7.2 & 8.7 & 7.0 & 6.4 & 6.5 \\
$30 \mathrm{~min}$ & 8.0 & 9.7 & 7.6 & 7.1 & 7.05
\end{tabular}

High-temperature fluid loss.

cc at $100 \mathrm{psi}$ and $212^{\circ} \mathrm{F}$

\begin{tabular}{lccccc}
$30 \mathrm{~s}$ & 2.4 & 1.0 & 3.0 & 3.0 & 3.3 \\
$1 \mathrm{~min}$ & 2.6 & 1.8 & 3.2 & 3.2 & 4.3 \\
$3 \mathrm{~min}$ & 3.2 & 2.8 & 3.8 & 4.2 & 5.8 \\
$5 \mathrm{~min}$ & 3.8 & 3.8 & 4.8 & 5.6 & 6.7 \\
$7.5 \mathrm{~min}$ & 4.9 & 5.4 & 5.8 & 6.6 & 7.6 \\
$10 \mathrm{~min}$ & 5.6 & 6.4 & 6.7 & 7.2 & 8.4 \\
$15 \mathrm{~min}$ & 7.2 & 8.6 & 8.4 & 8.8 & 9.9 \\
$20 \mathrm{~min}$ & 8.8 & 10.2 & 10.0 & 10.4 & 11.4 \\
$25 \mathrm{~min}$ & 10.3 & 12.0 & 11.2 & 12.0 & 12.8 \\
$30 \mathrm{~min}$ & 11.4 & 13.8 & 13.6 & 14.0 & 13.0 \\
\hline & & & & &
\end{tabular}

Mud density is one of the key parameters for successful drilling and affects the performance of drilling mud. The mud density measurements revealed that the density of each of the samples was $1.031 \mathrm{~g} / \mathrm{cm}^{3}$. It has been noted that the density of the samples taken from different locations would not change the drilling performance in drilling mud suspensions prepared with the same concentration of bentonite and water.

The gel strength is the shear stress measured at low shear rate after the mud was set quiescently for a period of time (10 seconds and 10 minutes in the standard API procedure). The minimum difference between the results of $10 \mathrm{sec}$ and 10 min was measured in the D1 sample as $3.0 \mathrm{lb} / 100 \mathrm{ft}^{2}$. This indicates that the $D 1$ sample has a higher cutting carrying capacity and thixotropic properties than the other mud samples. As a matter of fact, when circulation was over, suspended particles were prevented from collapsing into the bottom of the well. The problem of pipe sticking was also prevented due to gel strength. The initial gel strengths of the drilling muds should be high enough to prevent the cuttings in suspension from collapsing. Therefore, it is possible 
that the muds prepared with geothermal spring water cause high-pressure changes during maneuvering and it is likely to crack the weak formations.

It is observed that the fluid loss of all samples increased in the course of time at ambient and elevated temperatures up to $302^{\circ} \mathrm{F}$. When the API and the high-temperature fluid loss values at the end of 30 seconds and 30 minutes of each sample are examined, it is seen that the mud sample retained its stability and the lowest difference is the sample labeled as $D 1$. As the increment in the filtration rate of the fluid increases, the filtrate volume flowing into the underground formation may cause contamination of the production zone and/or deterioration of well stability. In all these cases, more filtration control agents will be required, and the cost of fluid will be directly affected.

After the API fluid loss test, the best filter cake measured by caliper of the mud samples is obtained for the $D 1$ sample with a value of $0.11 \mathrm{~mm}$. This indicates that the mud prepared by using geothermal water causes a thicker filter cake on wellbore during drilling operations compared to the freshwater muds. When geothermal water is preferred to prepare mud by operators, it will be more likely to encounter problems such as stuck pipe, excessive torque, drag, high swab, and surge pressures compared to freshwater muds.

\section{Conclusions}

As a result of experiments conducted on five different mud samples in order to compare the drilling performance of the drilling muds prepared with geothermal spring water and freshwater, the following conclusions were found.

(i) Muds prepared with geothermal water have lower viscosities and yield points than those prepared with freshwater at elevated temperatures. The stability of the muds deteriorates, and the muds start to become flocculated especially at temperatures higher than $250^{\circ} \mathrm{F}$. Moreover, since the viscosity and yield point of both types of muds are not high enough for drilling mud to perform its functions, this will lead to an increase in the amount of mud filtrate invasion and decrease the carrying capacity of drilling muds

(ii) The shear stress values at constant shear rate and shear thinning behavior of geothermal water-based muds are found to be lower than those of muds prepared with freshwater at both ambient and elevated temperatures. Therefore, these muds will exhibit lower flow performance, lower ability of hole cleaning, and lower rate of penetration compared to freshwater muds

(iii) Geothermal water muds lead to greater filtrate volume than that of freshwater muds at both ambient and elevated temperatures. In other words, it could be noted that there is an increase in the volume of filtrate flowing through the formation during drilling when geothermal water-based muds are used. It could also lead to contamination of the production zone and degradation of well stability. Therefore, it will require a significant amount of fluid loss additive to control the filtration. As a result, this will directly affect the cost of the well

(iv) Muds prepared with geothermal water are found to have a greater cake thickness than are muds prepared with freshwater. Therefore, it may cause the drill string to stick to the wellbore and increase the possibility of other damages inside the well due to higher swab and surge pressures

Briefly, it could be noted that the muds prepared with geothermal spring water will cause lower drilling performance and high cost compared to muds prepared with freshwater. Therefore, it is recommended that geothermal spring water should not be used to prepare drilling mud in terms of effectiveness and cost of drilling.

\section{Data Availability}

No data were used to support this study.

\section{Conflicts of Interest}

The authors declare that there is no conflict of interest regarding the publication of this paper.

\section{Acknowledgments}

The authors would like to thank Dr. Gursat Altun (Istanbul Technical University, Department of Petroleum and Natural Gas Engineering) for his valuable suggestions and for providing laboratory opportunities.

\section{References}

[1] A. T. Bourgoyne, M. E. Chenevert, K. K. Millheim, and F. S. Young Jr., Applied drilling engineering, vol. 2 of Society of Petroleum Engineers Textbook Series, , Society of Petroleum Engineers, 1991.

[2] R. Caenn, H. C. Darley, and G. R. Gray, Composition and Properties of Drilling and Completion Fluids, Gulf Professional Publishing, Amsterdam, 2011.

[3] V. C. Kelessidis, C. Tsamantaki, A. Michalakis et al., "Greek lignites as additives for controlling filtration properties of water-bentonite suspensions at high temperatures," Fuel, vol. 86, no. 7-8, pp. 1112-1121, 2007.

[4] Z. Luo, J. Pei, L. Wang, P. Yu, and Z. Chen, "Influence of an ionic liquid on rheological and filtration properties of waterbased drilling fluids at high temperatures," Applied Clay Science, vol. 136, pp. 96-102, 2017.

[5] M. Amani, M. Al-Jubouri, and A. Shadravan, "Comparative study of using oil-based mud versus water-based mud in HPHT fields," Advances in Petroleum Exploration and Development, vol. 4, no. 2, pp. 18-27, 2012.

[6] S. Saito, S. Sakuma, and T. Uchida, "Drilling procedures, techniques and test results for a $3.7 \mathrm{~km}$ deep, $500^{\circ} \mathrm{C}$ exploration well, Kakkonda, Japan," Geothermics, vol. 27, no. 5-6, pp. 573-590, 1998. 
[7] S. Saito and S. Sakuma, "Frontier geothermal drilling operations succeed at $500^{\circ} \mathrm{C}$ BHST," SPE Drilling and Completion, vol. 15, no. 3, pp. 152-161, 2000.

[8] S. Santoyo-Gutiérrez, A. García, M. Morales, J. Perezyera, and A. Rosas, "Applied technology in the solution of geothermal drilling problems of deep wells in La Primavera caldera (Mexico)," Journal of Volcanology and Geothermal Research, vol. 47, no. 1-2, pp. 195-208, 1991.

[9] B. Ma, X. Pu, Z. Zhao, H. Wang, and W. Dong, "Laboratory study on core fracturing simulations for wellbore strengthening," Geofluids, vol. 2019, Article ID 7942064, 18 pages, 2019.

[10] V. G. Gude, "Chapter 4 - geothermal source for water desalination-challenges and opportunities," in Renewable Energy Powered Desalination Handbook, pp. 141-176, ButterworthHeinemann, 2018.

[11] C. Vipulanandan and A. Mohammed, "Effect of nanoclay on the electrical resistivity and rheological properties of smart and sensing bentonite drilling muds," Journal of Petroleum Science and Engineering, vol. 130, pp. 86-95, 2015.

[12] R. Jain, V. Mahto, and V. P. Sharma, "Evaluation of polyacrylamide-grafted-polyethylene glycol/silica nanocomposite as potential additive in water based drilling mud for reactive shale formation," Journal of Natural Gas Science and Engineering, vol. 26, pp. 526-537, 2015.

[13] Y. Kang, J. She, H. Zhang, L. You, and M. Song, "Strengthening shale wellbore with silica nanoparticles drilling fluid," Petroleum, vol. 2, no. 2, pp. 189-195, 2016.

[14] J. Cai, M. E. Chenevert, M. M. Sharma, and J. E. Friedheim, "Decreasing water invasion into Atoka shale using nonmodified silica nanoparticles," SPE Drilling \& Completion, vol. 27, no. 1, pp. 103-112, 2012.

[15] M. C. Li, Q. Wu, K. Song, Y. Qing, and Y. Wu, "Cellulose nanoparticles as modifiers for rheology and fluid loss in bentonite water-based fluids," ACS Applied Materials \& Interfaces, vol. 7, no. 8, pp. 5006-5016, 2015.

[16] R. C. Navarrete, R. E. Himes, and J. M. Seheult, “Applications of xanthan gum in fluid-loss control and related formation damage," in SPE Permian Basin Oil and Gas Recovery Conference, Midland, TX, USA, March 2000.

[17] L. Yan, C. Wang, B. Xu, J. Sun, W. Yue, and Z. Yang, "Preparation of a novel amphiphilic comb-like terpolymer as viscosifying additive in low-solid drilling fluid," Materials Letters, vol. 105, pp. 232-235, 2013.

[18] V. Mahto and V. P. Sharma, "Rheological study of a water based oil well drilling fluid," Journal of Petroleum Science and Engineering, vol. 45, no. 1-2, pp. 123-128, 2004.

[19] H. M. Ahmad, M. S. Kamal, and M. A. Al-Harthi, "High molecular weight copolymers as rheology modifier and fluid loss additive for water-based drilling fluids," Journal of Molecular Liquids, vol. 252, pp. 133-143, 2018.

[20] X. Meng, Y. Zhang, F. Zhou, and P. K. Chu, "Effects of carbon ash on rheological properties of water-based drilling fluids," Journal of Petroleum Science and Engineering, vol. 100, pp. 1-8, 2012.

[21] T. N. Ofei, C. B. Bavoh, and A. B. Rashidi, "Insight into ionic liquid as potential drilling mud additive for high temperature wells," Journal of Molecular Liquids, vol. 242, pp. 931-939, 2017.

[22] V. C. Kelessidis, C. Tsamantaki, and P. Dalamarinis, "Effect of $\mathrm{pH}$ and electrolyte on the rheology of aqueous Wyoming bentonite dispersions," Applied Clay Science, vol. 38, no. 1-2, pp. 86-96, 2007.

[23] B. Abu-Jdayil, "Rheology of sodium and calcium bentonitewater dispersions: effect of electrolytes and aging time," International Journal of Mineral Processing, vol. 98, no. 3-4, pp. 208-213, 2011.

[24] D. Zhao, H. Liu, W. Guo, L. Qu, and C. Li, "Effect of inorganic cations on the rheological properties of polyacrylamide/xanthan gum solution," Journal of Natural Gas Science and Engineering, vol. 31, pp. 283-292, 2016.

[25] S. M. Willson, P. M. Driscoll, A. Judzis et al., "Drilling salt formations offshore with seawater can significantly reduce well costs," SPE Drilling \& Completion, vol. 19, no. 3, pp. 147155, 2004.

[26] J. H. Choi, C. S. Yoo, and Y. S. Han, “A study on engineering characteristics of the drilling fluid depending on the mix water," Journal of the Korean Geosynthetic Society, vol. 15, no. 4, pp. 43-52, 2016.

[27] H. Mao, Z. Qiu, B. Xie, Z. Wang, Z. Shen, and W. Hou, "Development and application of ultra-high temperature drilling fluids in offshore oilfield around Bohai Sea bay basin, China," in Offshore Technology Conference Asia, Lumpur, Malaysia, March 2016.

[28] American Petroleum Institute 13A, Specification for DrillingFluid Materials, American Petroleum Institute, Production Department, Bellevue, USA, 2010.

[29] American Petroleum Institute RP13B1, Recommended Practice for Field Testing Water-Based Drilling Fluids, American Petroleum Institute, Bellevue, USA, 3rd edition, 2004.

[30] K. Wang, B. Yuan, G. Ji, and X. Wu, "A comprehensive review of geothermal energy extraction and utilization in oilfields," Journal of Petroleum Science and Engineering, vol. 168, pp. 465-477, 2018.

[31] A. P. Tchameni, L. Zhao, J. X. F. Ribeiro, and T. Ting Li, "Evaluating the thermal effect on the rheological properties of waste vegetable oil biodiesel modified bentonite drilling muds using Vipulanandan model," High Temperatures High Pressures Journal, 2018.

[32] C. Vipulanandan and A. S. Mohammed, "Hyperbolic rheological model with shear stress limit for acrylamide polymer modified bentonite drilling muds," Journal of Petroleum Science and Engineering, vol. 122, pp. 38-47, 2014.

[33] A. S. Mohammed, "Effect of temperature on the rheological properties with shear stress limit of iron oxide nanoparticle modified bentonite drilling muds," Egyptian Journal of Petroleum, vol. 26, no. 3, pp. 791-802, 2017.

[34] R. V. Lauzon and K. I. G. Reid, "New rheological model offers field alternative," Oil \& Gas Journal, vol. 77, no. 21, pp. 51-57, 1979.

[35] D. Bonn, M. M. Denn, L. Berthier, T. Divoux, and S. Manneville, "Yield stress materials in soft condensed matter," Reviews of Modern Physics, vol. 89, no. 3, article 035005, 2017.

[36] H. A. Barnes, "A review of the slip (wall depletion) of polymer solutions, emulsions and particle suspensions in viscometers: its cause, character, and cure," Journal of Non-Newtonian Fluid Mechanics, vol. 56, no. 3, pp. 221-251, 1995.

[37] P. Skalle, Drilling Fluid Engineering, BookBoon, 2011. 

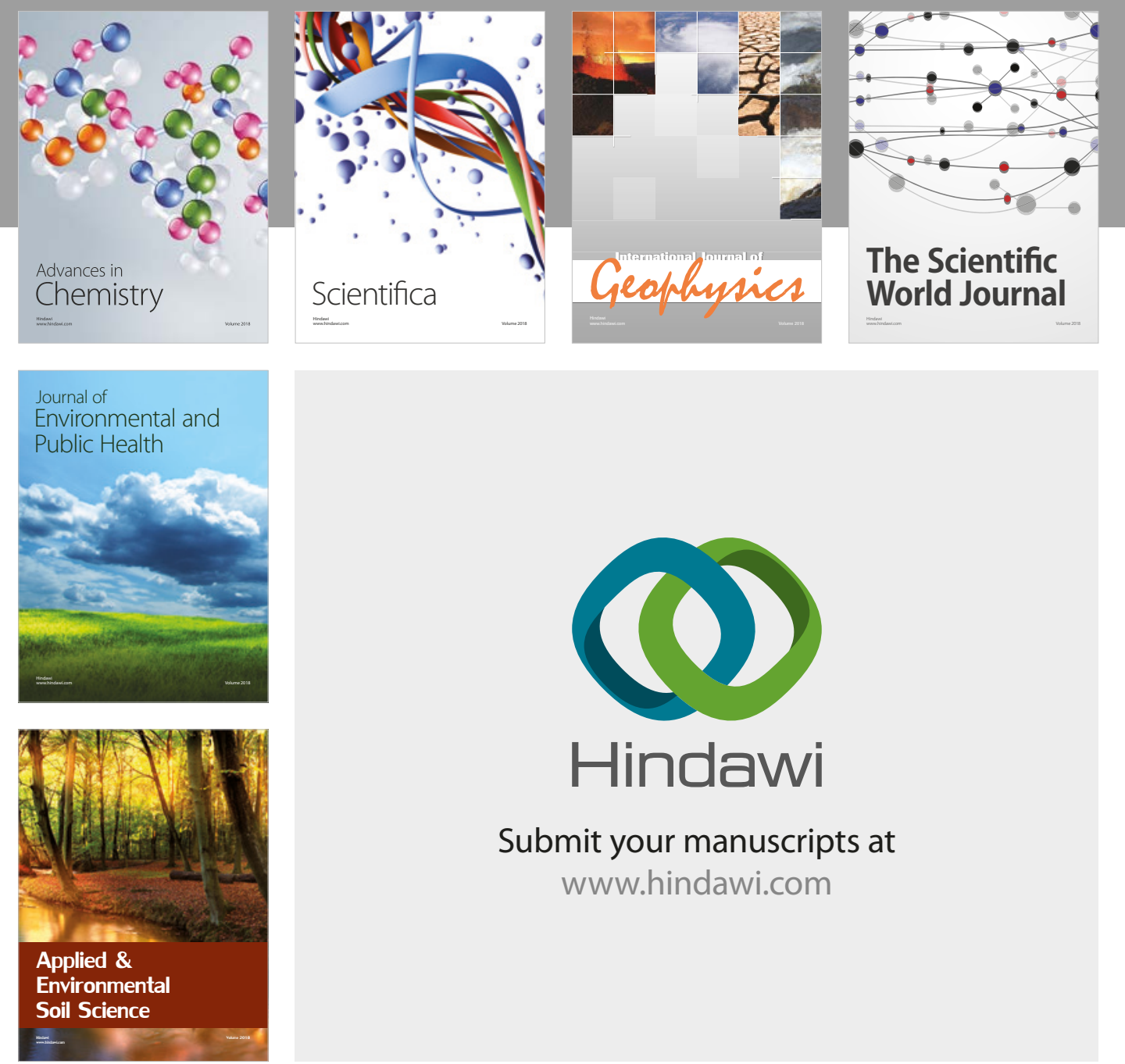

The Scientific

\section{World Journal}
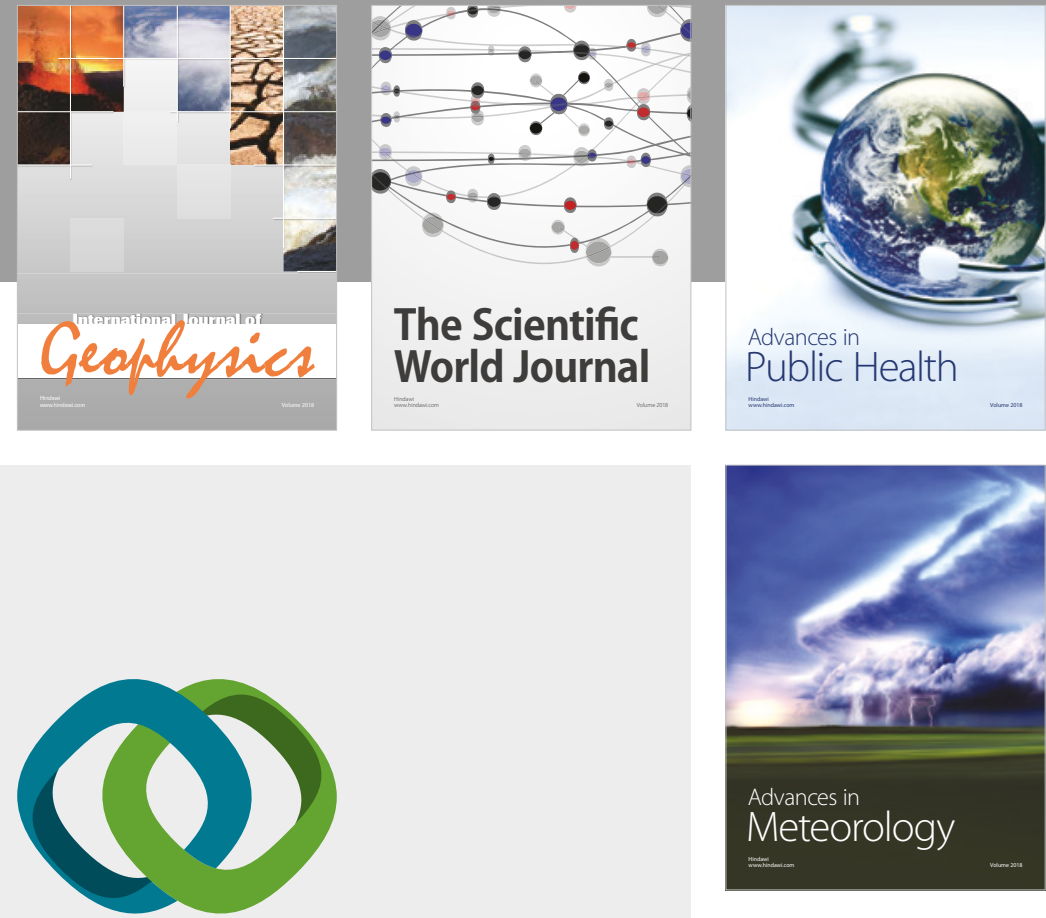

Advan

Public Health

\section{Hindawi}

Submit your manuscripts at

www.hindawi.com
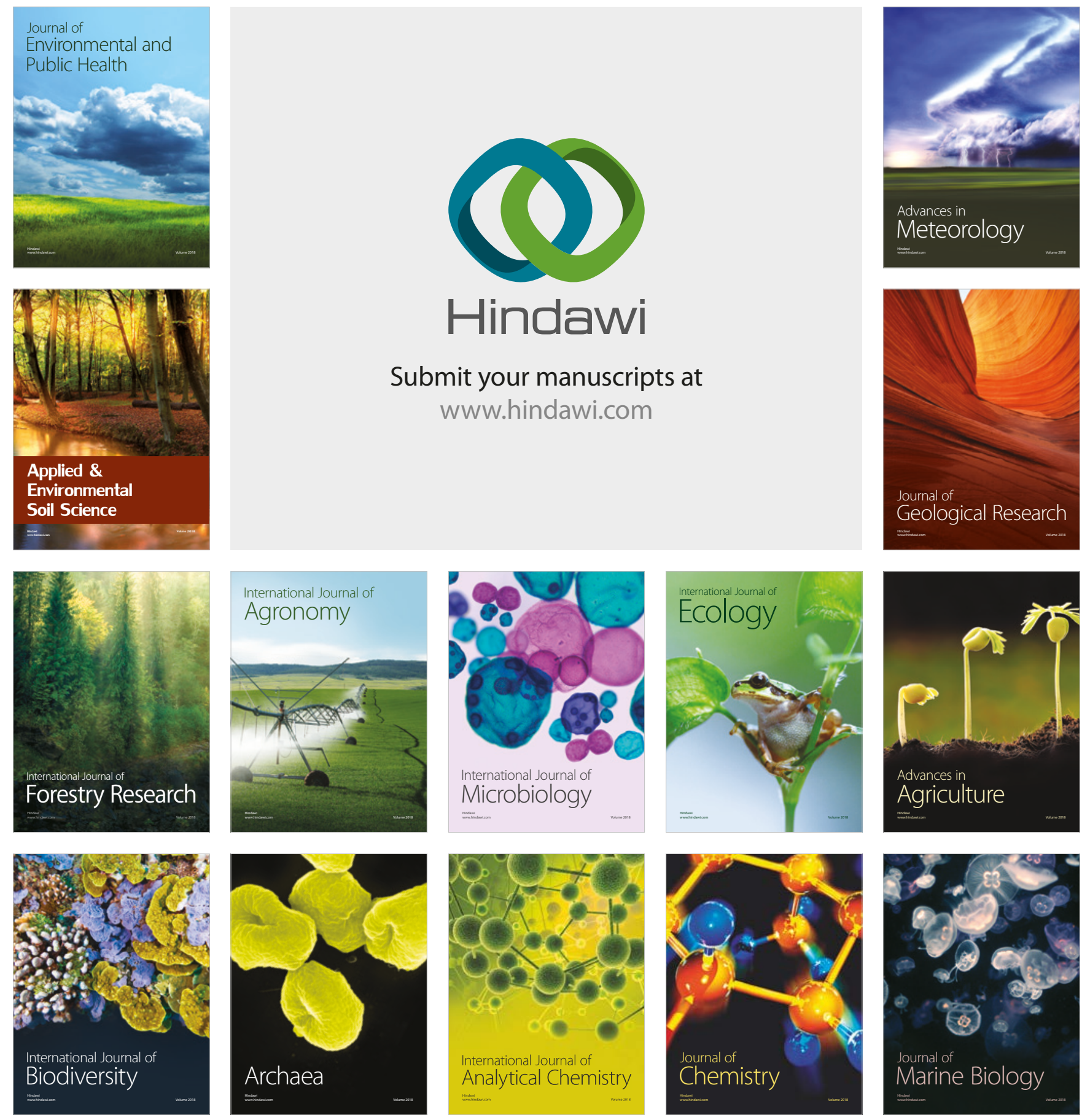